\title{
Summary of, and Response to, Critiques and Commentaries of Other Scholars on the Subject of Witch Accusations and the Church
}

\author{
Robert J. Priest
}

On Knowing Humanity Journal exists to foster knowledge informed by both anthropology and Christian theology. Perhaps no topic more clearly invites such an interdisciplinary conversation than the topic of Christian engagements with witchcraft accusations in the contemporary world. This is both because of the gravity of what is at stake in human lives, and because of the complexity of the issues and dynamics involved. Thus this journal publishes here a major research report and analysis (Priest, Ngolo, and Stabell, 2020) intended to foster such an interdisciplinary conversation. In addition, it has extended an invitation to selected Christian scholars understood to have knowledge or expertise on the topic-an invitation to first read the lead essay and then to write their own brief response articles-focusing selectively on whichever issues or dynamics they choose. Rev. Abel Ngolo, as the leader of EPED, has also written an additional brief report in his own words of the ministry of EPED. These additional articles are included in this theme issue, along with this final article intended to summarize and engage some of the issues raisedtowards the goal of helping focus an on-going project of conversation, research, analysis, and engagement. In short, this final article is not intended as a final word on the subject, but simply as an additional contribution to help to move the conversation forwards towards greater clarity in focusing questions, identifying what is at stake, carrying out follow-up research, and formulating proposals for the future.

It is a testament to the gravity and importance of our topic that nearly every person invited to write a response to the lead article, not only agreed to do so but actually completed their articles under rather tight time constraints. Contributers include anthropologists (Adeney, Gibbs, Jindra, McKee, McKinney, Ntarangwi, Rynkiewich, Zehner), a linguist-and theologian (Anguandia-Alo), a sociologist (Mtika), historians (Minkema \& Davis), world Christianity scholars
(Gifford, Gitau), missiologists (Lumeya, Chinyere Priest, Rasmussen, Sanou), an Old Testament scholar (Cookey Ekpo), theologians (Banda, Madueme, Mlenga, Mombo, Mpindi, Ngong, Nyasulu, Onyinah), and activists in combatting child-witch accusations (Howe \& Stockley, Ngolo, Obot). Over half of the authors are African (from Cameroon, the DRC, Ghana, Kenya, Malawi, Nigeria, Zimbabwe), with most of the rest having studied or served in Africa for years, or in other regions of the world where witch accusations are currently an issue (such as New Guinea). We should all be grateful to these many contributors who took their time to help us think through the issues and move the conversation forward.

It will not be possible to fully do justice to the rich and complex insights and arguments articulated in the above articles-which of course need to be read firsthand to fully appreciate. But in hopes of keeping the conversation moving forward, I will provide in this final review a summary of, and response to, some of the core critiques, suggestions, and elaborations found in the preceding responses.

\section{Theoretical Frames from Anthropology and the Human Sciences}

Any contribution to knowledge on a given topic will be stronger if the writer has a good grasp of prior scholarly conversations and theories on a given topic. And indeed there is a large prior scholarly literature on witchcraft by anthropologists and historians. Many of the respondents here make use of this larger literature and theory either to suggest further elaborations on how to understand the relevant social, cultural, or psychological dynamics in the Kinshasa material or in some cases to critique something asserted in the lead research article. We begin here with consideration of theoretical frames from the human sciences and defer 
to a later section the discussion of issues raised that are more properly theological in nature.

\section{Functionalism}

Several respondents (Adeney, Mlenga, McKinney, Minkema \& Davis, Sanou) either allude to "functional" dimensions of witchcraft and witchcraft accusations or reference literature that explores witchcraft from within such a theoretical frame. And indeed the majority of anthropological treatments of witchcraft of an earlier era adopted such a frame, as is perhaps evident in Dr. Miriam Adeney's helpful review (pp. 52-54) of some of this literature. In my view, there is an enormous amount to learn from this literature, and anyone wishing to engage the topic would do well to become familiar with this earlier literature. Indeed most respondents referenced such theory or writings in delimited ways that are largely compatible with our own analysis.

But since it was out of this functionist frame that Adeney raised a substantive critique of a core claim made in our original article, her critique merits sustained attention. We had argued (Priest et al., p. 44) that in traditional cultures with interpersonal causal ontologies (witch ontologies), "whenever misfortune strikes, major efforts are exerted to identify the evil witch causing the problem, with special techniques and power . . . [employed] to identify those [individuals] thought to have caused the misfortune of others." Adeney (p. 53) quotes us here and replies with a caveat that

this may not be the case everywhere. Clyde Kluckhohn asserted that Navaho ', who value intense interdependence but who can grate on one another when confined together in their winter hogans, find outlets for expressing anger by accusing witches who are unnamed and "far away." True, occasionally persons known and close at hand are accused. Then killing may result. But most accusations are against vague, distant witches. This allows Navaho an outlet for releasing stress while continuing to live together in harmony in close quarters (1944:89).
If I understand Adeney correctly, she is gently questioning both the sentence quoted and the assumption that traditional witch beliefs necessarily involve the larger complex of cultural patterns we described-and specifically our implied contention that witch ontologies rather consistently have negative social outcomes for actual people suspected and accused of witchcraft.

Anthropology is one of those disciplines where it is dangerous to make broad generalizations of the sort we provided since another anthropologist will frequently point out a culture where the generalization does not apply. But in this instance, I do not believe Navaho culture represents such a discrediting exception to what we claim, even based on a careful review of Kluckhohn's own landmark book. Adeney's summary of Kluckhohn is a plausible summary of Kluckhohn's argument ${ }^{2}$ and indeed is consistent with how other anthropologists have understood Kluckhohn (e.g. Douglas 1970 xxvi)-with witch accusations functional because primarily accusing vague distant witches, and thus not adversely affecting the accused.

But this seeming pattern appears to be partially a byproduct of Kluckhohn's interview method. Because of the Navaho's “extreme reluctance” (p. 13) to discuss witchcraft with him, ${ }^{3}$ Kluckhohn would elicit stories by saying: "I am sure you must have heard some good stories about witches. I wish you would tell me things you have heard" (p. 14). He says "most of the anecdotes" obtained related to "witches not in the immediate community but 'over the mountain,' 'across the reservation'-generally, the further away the better, it would seem" (p. 58). After years of research on the topic among the Ramah Navaho (a community of 500 members), he only heard whispers of three individuals within the community suspected of witchcraft. However, after additional years of research, he learned of twenty-six more individuals in this community accused of being witches (p. 58). This comes to a minimum of $4 \%$ of community members who were believed by other community members to have harmed someone in the community through witchcraft. Furthermore, when Navahos faced afflictions they suspected were caused by witches, they invited a diviner (either a "star gazer" or a "hand trembler") to help

${ }^{1}$ The Navaho are a Native American group located in the American southwest.

${ }^{2}$ Kluckhohn (1944: 96) writes, "the fact that a high proportion of witchcraft gossip refers to distant witches makes Navaho witchcraft much more adaptive than most patterns which center witch activity within the group.”

\footnotetext{
Such reluctance was at least partly based on the historical moment in which Kluckhohn carried out his research (1922-1959). In an earlier past, Navaho witch trials and executions were often public events, as when in 1884 the Navaho leader Manuelito supervised the trials and execution of more than forty witches, including his own brother (104, 112, 208). By the time Kluckhohn first began visiting the Navaho 38 years later, the Navaho were under the legal and penal system of the US government which banned such trials and executions, treating them as criminal events, thus making their continued presence less frequent and more surreptitious-part of the conditions that made research on the topic so difficult.
} 
identify the witch (p. 214)-which is what our quote above said was part of the pattern. Alternatively, the afflicted persons themselves took the hallucinogen peyote-with the most common reported peyote vision involving the identification of some specific person ("usually a relative or in-law") as the witch who has caused the dreamer's affliction (p. 232). I cannot find any stories in Kluckhohn's book where an individual suffering affliction blamed some distant unknown party in another settlement, providing a harmless functional "outlet" or "displacement" onto distant unnamed others. Rather, Kluckhohn acknowledges that the most common person suspected and accused when a person is actually suffering mysterious affliction is the sufferer's own brother or sister (pp. 26, 28, 102, 104, 112, 208), a maternal uncle (p. 59), or an affinal relative (i.e. a relative by marriage), with the "most frequent . . . involving a son-in-law accusing the father-in-law" (p. 59). That is, if one begins by asking for public anecdotes about witchcraft, one gets stories disconnected from the teller's own affliction and located far away. Such stories can be told publicly precisely because they are not disruptively implicating nearby listeners or anyone in their family of being a secret murderer. But if one comes alongside afflicted individuals struggling to identify the persons understood to have caused their afflictions, then one learns it is close relatives that are suspected, with forms of divination used to help confirm suspects.

What happens to the accused among the Navaho? "If someone is sick," perhaps after a "star gazer" or "hand trembler" or peyote vision has identified a suspect, the "suspected witch" is summoned to a meeting, frequently after being tied with a rope and led to the meeting. There he ${ }^{4}$ is questioned. If he refuses to confess, "he is tied down and not allowed to eat, drink or relieve himself until he confesses" (p. 48). "Hot coals" may be applied to his feet, to encourage confession (p. 49). Kluckhohn tells us, "if a witch refused to confess within four days, he was most often killed" (p. 49), often "by a group of relatives (and friends) of some supposed victim. The manner of execution varied but was usually violent-by axes or clubs" (p. 49). And again, "The killing of witches is uniformly described as violently sadistic" (p. 98). "In some cases, the accused was allowed to escape if he permanently left the community" (p. 48).

During the functionalist era of anthropology, while historians of European witchcraft viewed witchcraft beliefs as destructive and tending toward violence (and focused on consequences of witch accusations for the accused), anthropologists, as Mary Douglas (1970, xiii) points out, argued that "the same beliefs in Melanesia or Africa . . . served useful functions.” Kluckhohn's arguments exemplify such a functionalist logic. But his actual descriptive data (much of it buried in notes) fully supports the generalizations we provide on cultural patterns that accompany witch ontologies, patterns with decidedly negative consequences for significant numbers of accused people.

Indeed, unlike the majority of earlier functionalist anthropologists, our Kinshasa research, as well as many of our respondents (Chinyere Priest ${ }^{5}$, Cookey Ekpo, Gibbs, Howe and Stockley, Minkema and Davis, Ngolo, Obot, Rasmussen), placed the accused, and negative outcomes for the accused, at the center of research, analysis, and concern.

Thus, in his response, Reverend Abel Ngolo clearly does not view child-witch accusations as functional. He reports (p. 111) that "today, accusations of witchcraft are a veritable tsunami, a tidal wave that is sweeping across all of Congolese society," with "so-called child witches-or more accurately, children baselessly accused of witchcraft" being identified as the primary "scapegoats" for the problems families experience. He writes, "it is unquestionably the case that the main actors in the validation of child-witch accusations come from the ranks of pastors, shepherds, apostles, prophets, archbishops and other Christian leaders" (p. 112). The result, Ngolo tells us, is

that there are thousands and thousands of children who are tortured and at times burned to death, who die of hunger, who are driven from their family home and who are then forced to live on the streets. All this happens because, in the name of the church, some of its leaders practice a type of "therapy" that is criminal in nature, wrongly accusing children as witches. (p. 112)

Readers will, of course, wish to read Ngolo's full article (pp. 111-114).

Dr. Chinyere Priest (pp. 135-136) also places the accused, and negative outcomes for the accused, at the center of her analysis. She first focuses discussion on the case in our report of the accused child Sylvain Mbaki, and then describes and analyzes another single case of an accused Nigerian child: herself. As a result of childhood sexual abuse and related symptoms of trauma, combined with being born a triplet, as a child Chinyere was labeled Ogbanje, a witch thought to be the cause of family misfortunes. She writes,

\footnotetext{
${ }^{4}$ Among the Navaho, most accused witches are male.

Despite having the same last name, Dr. Chinyere Priest is not related to Robert Priest.
} 
This label influenced my behavior and selfperception. I would often stay alone in a dark room; I avoided contact with peers, limited my conversation with family, hated the opposite sex, and was fearful and timid. I thought of myself as a failure, as unwanted, unloved, foolish, and a nobody. (p. 136)

After living this way for two decades, she describes entering a different social "environment" where Ogbanje was no longer her identity, and where others viewed and labeled her as "intelligent, wise, and important." She says "this changed my whole outlook to life, self-esteem, and behavior." Although she does not spell it out, this transformation opened doors to her for ministry and academic success at the highest levels. She argues that the witch label itself was destructive, and its removal liberating. Dr. Chinyere Priest ends her article calling for readers to become sympathetic advocates and defenders of accused children, victimized through witch labels, and grounds her call in biblical mandates.

From New Guinea, with a parallel focus, Dr. Philip Gibbs (pp. 65-68), an anthropologist and Catholic priest, reports on his team's three-year investigation into 557 people accused of witchcraft/sorcery-with careful research and analysis into who is accused and with what negative consequences. Similarly, Dr. Steve Rasmussen (pp. 137-141) describes how he and his Tanzanian Pentecostal colleagues and pastors went through a paradigm shift together, where they carefully tracked witch accusations, listened to the stories of those accused, examined the suspicious nature of the accusations, identified negative consequences to the accused, reconsidered biblical teaching on the matterand came to actively resist the witch accusations themselves as negatively problematic.

Several respondents indirectly allude to the possibility that there may be models of church engagement where church leaders both confirm the child-witch diagnosis and intervene in a way that truly contributes to the long-term flourishing of the formerly accused. While I do not think current research encourages us to believe this is likely, clearly more research is needed that explores outcomes for the accused under variable ministry paradigms.

\section{Feminism}

Feminism has provided another influential theoretical approach in the study of witch accusations, as briefly mentioned by various respondents. This is in part because, as Minkema and Davis report "women, and especially elderly and poor ones, were disproportionately accused, and women were among the great majority of those executed, to the extent that the European witch-hunt has been equated with gynocide, or women-hunting” (p. 96). Dr. Michael Rynkiewich reports that "women are disproportionately accused worldwide” (p. 142), and Dr. Boubakar Sanou reports that in much of Africa, "the face of witchcraft" is often feminine (p. 146).

Feminists, unlike functionalists, have not been inclined to view such a cultural pattern of accusing and prosecuting women as witches as something functional or defensible, but rather as exemplifying victimization of women. But how exactly does this theoretical approach relate to our own research on child-witch accusations? I suggest that feminist assumptions or concerns show up in responses in a couple of ways.

Dr. Esther Mombo (pp. 103-104), a Kenyan theologian and member of the "Circle of Concerned African Women Theologians," richly describes the recent funeral of her mother and compares it to the funeral of her father 30 years earlier. She says the majority of Abagusii ${ }^{6}$ funeral participants were Christian but oscillated "between two world views" and were preoccupied during the funeral with witchcraft in ways that had not changed in thirty years. Only at the end does she briefly consider the Kinshasa material which is where she alludes to feminism. She writes,

in most of the stories about children accused of witchcraft, the child has a sad background of not being wanted. . . The child . . . is a burden to the family and to get rid of the child, the child is accused of being a witch . . . Until we sort out issues of 'unwanted children ..., children will continue to be accused of witchcraft to enable families to get rid of them. Witchcraft is not the real issue; the real issue is how we deal with a patriarchal society where children who do not fit a family setting as a result of a broken marriage or the death of a parent will continue to suffer. So it is not witchcraft that is the problem, but it is a peg on which questions of life are hung. (p. 104)

Dr. Mombo's reference to patriarchy as Kinshasa’s root problem reflects feminist thought; but in the absence of further clarification from her, I am puzzled to see how she understands the Kinshasa data to fit this diagnosis. ${ }^{7}$ However, it is another aspect of Mombo's

\footnotetext{
${ }^{6}$ The Abagusii are also known as the Kisii or the Gusii.
}

In Kinshasa, boys are accused as often as girls. And women are accusers, as well as men. Both male and female pastors, prophets, and intercessors participate in the rituals of deliverance. Indeed, the most famous pastor worldwide whose ministry focuses on childwitch accusations is a woman, the Nigerian Pastor Helen Ukpabio. Even cross-culturally, as Dr. Mombo, and Dr. Adeney both 
comments I wish to focus on here. As a feminist, Mombo perceives witch accusations (whether directed at women or children) not as stemming from purely good-faith efforts to act on what belief requires, but as serving instrumental and selfish goals-including centrally the goal of justifying oneself in eliminating an unwanted dependent. I do not think her insight requires the idea that people are necessarily deliberately and self-consciously lying, claiming to believe what they do not believe, for us to understand that instrumental considerations on the part of accusers might well have a contributing impact on the process. Mombo's perception of accused children as probable victims is likely an extension of her earlier feminist recognition of how frequently accused women have likewise been victims of similar accusations.

In short, many people who view accused children as victims, are uninclined to view accused adults within a similar frame. But it has been the prior feminist recognition of accused women as victims also that provides pressure and justification for broadening our concerns to other categories who suffer as a result of witch accusations.

Consider Dr. Rasmussen's response. He reports (p 138) that in Tanzanian communities people "regularly neglect, beat, fine, or chase away people suspected of being witches, especially older, divorced or widowed women" (emphasis added). Houses are burned, property confiscated. Hundreds, he tells us, are hacked to death with machetes each year, according to official police records. ${ }^{8}$ It is in this context, a context where older women are the most common victims of witch accusations and violence, that a group of Tanzanian Pentecostal pastors, not unlike the EPED pastors of Kinshasa, have mobilized in defense of elderly women (and others) increasingly understood as victims of false witch-accusations and associated violence. As Rasmussen stresses (p. 137), when it comes to witch accusations and accompanying consequences, "across the world, people harm the poor, elderly, outsiders, and women much more than children." " In short,
Rasmussen warns us, it would be a mistake for readers of the Kinshasa report to imagine that the only real victims of witch accusations that merit our concern are children. This report has broader potential implications for other categories of accused people, not least, women.

\section{Psychological Analysis}

Some scholars of witchcraft have contributed psychological analyses of witchcraft accusations. Kluckhohn, for example, merged functionalist with psychodynamic analysis-using psychoanalytic concepts like the unconscious, projection, compensation, outlet, displacement of aggression, scapegoating, wish fulfillment, etc. There is much to learn from his analysis.

While various respondents make brief allusions to psychological dynamics, only Dr. Wanjiru Gitau (pp. 72-73) makes them central to her analysis. In her response, Dr. Gitau, winner of Christianity Today's "2019 Book of the Year Award in Missions \& the Global Church," adopts a theoretical frame from the psychologist Erich Fromm, and suggests we shift our focus from the accused to the accusers, and specifically, to the "pathological narcissism of accusers" (p. 72)those who start and perpetuate the whole spiral of accusations and who ensure everyone becomes an accomplice in the accusations. Her exposition is highly suggestive, although as she recognizes, it would need further work to fully demonstrate. It would be interesting to see her take noted witch hunters from European history (Heinrich Kramer, Matthew Hopkins, Cotton Mather) or from African history (such as Nchimi Chicanga or Simbazako, as alluded to by Mtika, p. 109) and attempt to demonstrate the value of this theoretical frame for making sense of their motivations and dispositions. I am open to further persuasion should such a compelling analysis be provided, especially if the analysis is recognized as, at best, a partial analysis. ${ }^{10}$

acknowledge, there are cultures where men are accused more than women. In New Guinea, according to Dr. Gibbs' statistics, there are regions of New Guinea were women are accused most often, and other regions where men are accused most often.

${ }^{8}$ Formally reported by the Tanzanian Human Rights Reports (with statistics from 2005 to 2018).

${ }^{9}$ In his article, Gibbs reports that in their examination of over 500 cases of witch accusations in New Guinea, only two involved children under 11, with another 21 cases between ages 11 and 18.

${ }^{10}$ To clarify, in many regions of the world, witch accusations are not driven by professional witch hunters, but by the afflicted in
everyday life who, with the assistance of family and friends, take the initiative to invoke the help of diviners in confirming what they
already suspect. So the analysis would need to be nuanced in a way that recognizes the diverse categories of people involved in
accusations. I suspect Dr. Gitau's suggested explanation of narcissism pertains to, at best, a sub-set of those involved in witch
accusations-although perhaps a sub-set with disproportionate impact. Furthermore, the idea that a subset of humans, witch-accusers,
are uniquely "hardwired to carry out evil" (Gitau, p. 73) seems to me to err in the same way the original child-witch accusations err,
that is by attributing exaggerated evil to a small sub-set of people, rather than recognizing the relevance of shared sinful inclinations in
all humans. Finally, ideas, and not just psychological syndromes, have consequences. Part of the reason people attribute their 
But whatever the limits of "narcissism" as an explanation, Gitau does provide an important suggestion. While witch accusers invite us to imagine evil in the accused, Gitau suggests we shift our focus rather to the moral agency of the accusers, and their often sinful and self-serving motivations. Gitau could easily have cited René Girard to this effect, the theologian that Dr. Michael Jindra cited in his response. Girard (2001) points out that when we accuse another of evil, we easily imagine ourselves as a righteous person combatting evil, doing the very work of God. But he points out that frequently the Bible names Satan as the great accuser-who through deceptive accusations and evil motivations sows discord, fear, distrust, violence, and death. In short, Girard suggests that witch accusers, rather than exemplifying the character and work of God in opposing evil, may well exemplify the character and work of Satan in furthering evil by means of false accusations. For Girard, such tendencies are primordially human, potentially present in all of us, not merely in the sub-set of those identified here as witchaccusers.

But setting aside biblical interpretation, Gitau's suggestion that we consider the self-serving and flawed motivations of accusers, merits brief elaboration. This can be as mundane as Dr. Mombo's observation that a parent in poverty, desperately wishing not to share her own child's limited food with a step-child she is responsible for, might be motivated to endorse a witch accusation that relieves her of further responsibility for the step-child. Again, when a married man dies, and his brothers show up to accuse the widow of having killed him through witchcraft-the possibility that this serves their purposes of appropriating marital assets without obligations to care for the widow should be considered. Who benefits by the accusation? As historians of early Euro-American contexts, Minkema and Davis (p. 96) likewise find that witch accusations and executions "functioned as a way to remove burdensome weight from the community," conveniently enabling communities to avoid compliance with actual "laws" requiring them "to care for the poor, the ill, and the handicapped.”

A slightly more complex psychological dynamic relates to envy. In a now classic article, the anthropologist George Foster (1972) demonstrated that around the world one of the most pervasive human dynamics is a fear of envy in one's relatives, colleagues, or neighbors. Thus when a woman gives birth in the presence of a barren neighbor, when one person eats food while a hungry relative watches, when one person is healthy and another sick, when one person achieves success and another failure-Foster points out that those who have more (more fertility, food, health, wealth) typically experience discomfort and anxiety in the presence of others who lack what they have, and who are assumed to be envious, maliciously so. People fear those who envy them and are inclined to attribute their misfortune to any nearby person thought of as envious. A woman whose baby dies when a barren woman is nearby easily attributes the death to the barren woman. Her own psychological fear of the barren woman's envy provides the hypothesis for the accusation. ${ }^{11}$

The noted historian Alan McFarlane has suggested that guilt, transformed into anger and fear, also sometimes underlies witch accusations. He noted that in European history when destitute widows continually approached their neighbors for food, those neighbors often turned them away-sometimes with an insult to discourage them from asking again. Rather naturally, vulnerable and desperately poor and hungry people whose requests are insultingly denied, are not happy people. McFarlane argues that he finds evidence that the consciences of many British more prosperous neighbors had been influenced by an ethic that told them they should help their poor neighbors. So when they refused to help, they felt guilty. But rather than acknowledge their discomfort as guilt, something to be repented of, they simply resented and felt angry towards those who made them feel this way. Anger, of course, seeks justifications that attribute evil towards the person one is angry at. And when one feels guilty, one implicitly feels afraid and imagines dangers. As the Bible articulates the psychological principle, "the wicked flee [even] when no one pursues" (Prov 28:1). Thus, the people one has sinned against, are often the very people the accusers fear, and later suspect, accuse, and prosecute as witches. And if the hungry person you turned away is really a witch, then there is no need for guilt in having turned them away. One's anger at them is not misplaced. They deserve what they get when they are named witches and treated as such. The case literature on witchcraft is littered with examples of people accusing as witches the very people they themselves had earlier sinned against.

misfortunes to other people thought of as witches is because they have been inducted into an idea system that cues them to interpret their afflictions in this way. This holds true even for people who are not unusually narcissistic.

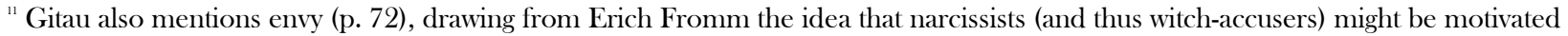
by their own envy. And while one can certainly find instances of people accusing other people who are better off than they are of harming them through witchcraft, the more frequent pattern as exposited by Foster involves people accusing others who are less well off of having caused their misfortune through witchcraft. Thus, Foster's argument moves in the opposite direction. On his model, witch accusations are commonly motivated by fear of the envy of those around them who are less well off. 
One of the most puzzling patterns we find with witch accusations worldwide is that those most likely to be accused are weak, handicapped, poor, strangers, orphans, widows, women, and the elderly. That is, people who by any normal measure are weak and powerless are imagined to have incredible power and privilege. But of course, if the psychological roots of witch accusations are underpinned by fear of the envy of less fortunate people around us, or by fear grounded in unacknowledged guilt for our failures to care for the weak and helpless among us, or grounded in an impulse to deny guilt by insisting the person we refuse to help is really an evil witch, not a victim, then it makes perfect sense that the targets of witch accusations would be the very people who, by any normal measure, are the weakest and most in need of help.

Of course, it is helpful to consider not only psychological dynamics in the lives of accusers but also in the lives of the accused. While none of the respondents attempts a fully psychological analysis of dynamics in the lives of accused children that might make them exhibit patterns likely to result in witchaccusations, allusions to such dynamics are widely present (see Cookey Ekpo, Howe \& Stockley, Chinyere Priest, Ngolo, Onyinah). We've already summarized Dr. Chinyere Priest's analysis above, where she describes the psychological outcomes of being sexually abused and labeled Ogbanje (wishing to be alone in the dark, avoiding social contact, being fearful and timid, hating males) as providing the very pieces of evidence that could then be pointed to as proof that she was a witch.

Rev. Abel Ngolo, after detailing the sorts of tragedies and traumas experienced by those most likely to be accused (the death of parents, family breakups, extreme poverty, mistreatments), paraphrases the psychiatrist Marie-France le Heuzey, stating,

children accused of witchcraft feel that they have lost control over their lives. They constantly replay past scenarios of abuse through repetitive games involving all or part of the trauma they have experienced, or through recurring nightmares full of terrifying content. Sometimes traumatic memories reappear in the form of hallucinations. Children who have experienced rejection of this kind sometimes succumb to sleep disorders. They may have trouble falling asleep, or find that they wake up during the night for no reason. This can lead to irritability, anger, difficulty in concentrating, a decline in academic performance, and other behavioral struggles. (p. 112)

Much then of the training by EPED and by Howe and Stockley features a straightforward discussion of normal developmental processes in children. But since neither our own original article nor responses of others provide much in the way of sustained interaction with relevant theory for analyzing this, we limit our comments here to the observation that clearly this is an area where a great deal more should be considered and explored.

\section{Dynamics Related to Urban, Postcolonial, Neoliberal Contexts}

An earlier anthropology of witchcraft was often functionalist, and often assumed the gradual disappearance of witchcraft discourses under modernity. But the more recent resurgence of witchcraft as a focus of study in anthropology, led by such scholars as Peter Geschiere and John and Jean Comaroff, suggest that conditions of modernity in urban, media-saturated, postcolonial, and neoliberal contexts (contexts stressing free market capitalism combined with extremely limited social services) provide an unusually fertile soil for the flourishing of witchcraft discourses. In his response, Dr. David Tonghou Ngong (pp. 115-117) cites from such an anthropological literature, arguing that African modernity exhibited a comparatively "dark side of modernity"-one that contributed to the "marginalization of the many who live in conditions of what has been described as abjection" (p. 117). He suggests that under such a "rapacious" version of metaphorically "cannibalistic" modernity, it should not surprise that witch accusations flourish (p. 117). In addition to Ngong, three anthropologist respondents (Dr. Mwenda Ntarangwi, pp. 118-121; Dr. Michael Jindra, pp. 79-80; and Dr. Michael Rynkiewich, pp. 142-144) insightfully explore some of the contemporary dynamics which this more recent scholarship of witchcraft considers, dynamics which in Kinshasa become a "perfect storm" (to cite Jindra, p. 79) for the flourishing of witchcraft anxieties. Readers are encouraged to read their response-articles, which provide analyses largely consistent with our own understanding of social realities in Kinshasa.

However, one respondent concludes his otherwise excellent analysis with an argument that implicitly disagrees with a core element of our own analysis, and thus requires more sustained consideration. Rynkiewich (p. 143) identifies the worsening situation in New Guinea after colonialism with respect to 1) "lack of adequate healthcare" and 2) "lack of trained and resourced law enforcement" as the two primary factors contributing to witchcraft accusations and violence. Church plans to combat witchcraft accusations, such as in the Congo, are "treating the symptoms," he argues, not the causes. He concludes his essay, "why would the church not want to start with root causes to reduce witchcraft accusations and violence?" 
At one level this seems straightforward. If there were no suffering or affliction, for example, there would be no allegations that one's suffering and affliction are caused by witches. Any successful attempt to diminish the amount of suffering and affliction which people experience will naturally tend to diminish the frequency with which people attribute witchcraft harm to others. ${ }^{12}$

But it is not true that material conditions involving affliction and suffering automatically cause witch accusations. It is possible to have great suffering without attributing it to relatives or neighbors thought of as witches. The Sirionó of Bolivia, with whom I grew up as the child of missionaries, experienced extreme poverty, violent predations from non-Siriono, social oppression, epidemics that wiped out large numbersand never attributed any of their misfortunes to neighbors or relatives thought of as witches. This was not part of their worldview. Similarly, Koreans have had a long history of being invaded and oppressed by neighboring powers, with lower classes (minjung) and women often experiencing great suffering and oppression, and with a primary role of the Korean shaman (the moodang) being to address the unresolved suffering (han) people experience. Indeed, there are whole theological traditions in Korea that emerge from reflections on human suffering (on han). But Koreans, whether shamans or pastors, do not attribute misfortune to witches. Material conditions do not automatically produce witchcraft ontologies.

Meanings matter, and are not merely "secondary symptoms" or effects "caused" by material conditions. Indeed the need for meaning, and not only for material supports, is central to the human condition, something stressed by anthropologists like Clifford Geertz, theologians like Samuel Kunhiyop (2002), as well as implied by Jesus when he affirmed, "Man shall not live by bread alone" (Mtt 4:4). The word used by a majority of our respondents to name the fact and importance of variable meaning patterns is the term "worldview" (Adeney, Banda, Gibbs, Gifford, Madueme, Mlenga, Ngong, Nyasulu, Rasmussen, Sanou). No materialist underpinnings automatically or necessarily produce a particular worldview, although all worldviews are of course efforts to make sense of human experience. And if one examines religious traditions inductively, it quickly becomes clear that a primordial root of all human religious systems is the effort to make meaning in the face of human experiences of affliction and death (Kunhiyop 2002). And the way cultures make meaning of suffering and affliction varies. In some places, people's explanations of misfortune stress a logic of karma, that everyone is only getting exactly what they deserve-perhaps based on sins in a prior life. In other places, people explain misfortune by reference to neighbors, relatives, or colleagues thought to have caused the misfortune through witchcraft. Other cultures stress other logics (see Shweder 2003, 74-133).

Our own analysis does not privilege either material conditions or meanings as more basic than the other but rather treats each as central. The reason this research focused heavily on the role of meaning is because we were empirically investigating not business leaders, government officials, medical personnel, or development agency staff-but pastors. And pastors, at the core, are in the meaning-making business. They help people make sense of afflictions and how to resolve them. We argue that in Kinshasa they play a central role in justifying and propagating child-witch accusation discourses. Having said that, as we demonstrated in our report, the pastors associated with EPED engage both with meaning and with modest efforts straightforwardly to help address material conditions related to issues of family illness, poverty, and discord.

Consider Rynkiewich's emphasis on better training and material support for police. The suggestion that police (and the judiciary) are actors that can truly make a difference to child-witch accusations is endorsed by other respondents also (see Anguandia-Alo, Howe and Stockley, Ngolo, Obot, Onyinah). But again, a strengthening of laws and police presence not accompanied by a shift in understood meanings does not consistently produce desired results. In Malawi, for example, to accuse someone of being a witch was made a prosecutable offense in 1911. And as both Dr. Mlenga (pp. 99-102) and Dr. Nyasulu (pp. 122-128) point out, historic Malawi churches, such as the Church of Central Africa Presbyterian (CCAP), likewise put into place policies prohibiting witch accusations and prohibiting church members from visiting diviners for help in identifying the suspected witch responsible for their affliction. Despite laws and church rules, both Mlenga and Nyasulu indicate that a high proportion of Malawians, including faithful church members, continue to believe that their misfortunes are caused by relatives or neighbors who are secretly witches, and they continue to believe that diviners can correctly identify those harming them through witchcraft. Nyasulu shows from his dissertation research that within a ten-year period, 595 people from eight large CCAP congregations were placed under church discipline for consulting diviners for help in identifying witches ( $p$.

\footnotetext{
${ }^{12}$ Dr. Mwenda Ntarangwi (p. 120), however, questions whether local churches and pastors "have enough resources to set up families materially so that they are independent and don't find themselves in another situation of material want and revert to reducing the number of dependents through witchcraft accusations?" And even under improving economic conditions, tragedies still occur. That is, I understand Dr. Ntarangwi as affirming that the solution cannot simply be a material solution.
} 
124). Church rules were in place, and enforced, forbidding the practice of consulting diviners to help identify witches. But church members were still convinced their afflictions were due to witches. And so, like King Saul who visited a diviner from Endor under cover of darkness (I Samuel 28), many CCAP Christians continue surreptitiously to seek wisdom from diviners. Belief matters.

Similarly, as Dr. Collium Banda points out in his reply, Zimbabwe has long had laws that forbid "labelling any person a witch.” But witch hunts continue to thrive, in part, because relevant "authorities and ordinary people believe in the genuineness of the witch-hunts" (p. 58). When the police themselves believe community deaths are actually caused by secret witches in their midst and believe witch hunters are truly identifying the murderous persons causing the deaths, they are unmotivated to actively prosecute anyone for identifying such persons as witches. And community members at large, who likewise believe the charges, are unlikely to notify and appeal to the police or other authorities to intervene. The issue here is not merely a matter of having a materially well-supported police force but involves at the core the question of what people believe to be true.

And a significant proportion of contemporary Africans, as many of our respondents point out, do believe that some people cause harm to others through witchcraft. A law telling them not to say what they actually believe to be true is unlikely to have an optimum impact. Consider the noted Congolese theologian, pastor, and author Rev. Dr. Paul Mbunga Mpindi, whose weekly radio broadcast is heard across Francophone Africa. In his response to our Kinshasa report, Dr. Mpindi (pp. 105-107) tells us about a young brother and sister (10 years old and 14 years old) who caused their father's blindness through witchcraft and affirms that children do harm others through witchcraft. I will address his response further below but wish here merely to suggest that a law forbidding him to say what he believes is of limited value. And what pastors and theologians such as Dr. Mpindi believe and teach is not a secondary matter, but powerfully shapes the meanings people live by and act upon.

In the case of Rev. Abel Ngolo and the EPED network of pastors in Kinshasa that work with street children, it is true that they highly value the Congolese law against labeling any child a witch. And they are networked with both police and the judiciary. On selected occasions with particularly serious cases of abuse, they have reported pastors to police, and have helped secure their prosecution, conviction, and imprisonment. But their primary use of the law is in appealing to it in their training, and in their interventions on behalf of children. But here is the point: It is only because these pastors have gone through a process where they themselves have come to see child-witch accusations and accompanying practices as invalid that they actively (and selectively) utilize the law and its enforcement agents against what they now see as abusive practices. Indeed, as is also emphasized in Howe and Stockley's article on various parallel networks of pastors organized to combat child-witch accusations, pastoral training related to child-witch accusations is often broadened to include relevant community partners, including the police. That is, unless police also go through a transformative process intellectually, they will be less than helpful partners in protecting such children. Likewise, the fact that the Tanzanian Pentecostal pastors that Rasmussen reports on make explicit use of police (pp. 138-139) in their activist engagement on behalf of accused elderly women is because they have actually gone through a paradigm shift where they no longer are inclined to agree that these women are truly secret killers in their midst. Only where believed meanings and laws are congruent does one find positive cooperative synergies between Christian leaders and legal enforcement, as evidenced among selected networks of pastors in Kinshasa and Tanzania.

In summary, to address relevant meanings is not to address merely secondary symptoms-but in fact, addresses an essential precondition for adequate engagement. Indeed, I suggest that pastoral and theological engagement has greater potential to make a difference across the continent of Africa than simply adding additional laws and providing more support for police. And indeed, it is not secular human rights activists or secular anthropologists that are in a good position to foster such a constructive reconsideration of meanings. Rather African Christian theologians are in the strongest position to make a difference-because only they have the authority and trust to engage fully at the level of ideas. The very reason that this report was placed in this explicitly Christian journal, and with African theologians invited to engage a conversation with Christian anthropologists, historians, and others on these issues, is out of the conviction that meanings matter, that the meanings which pastors embrace and communicate in their ministries have great potential for affecting human lives, and that African theologians are in a unique position to influentially engage African pastors as well as broader Christian audiences.

Contemporary secular anthropologists who write about witchcraft from the tradition represented by Geschiere and the Comaroffs typically treat witch discourses as symbolic and metaphoric commentary on unjust social power dynamics under postcolonial and neoliberal/capitalist material conditions, a symbolic way of "expressing discontent with modernity and dealing with its deformities" (Comaroffs 1999, as quoted by Ntarangwi 2020, p 119). Witch accusations, in this 
tradition, seldom are analyzed with a focus on the negative social outcomes which the accusations themselves produce. ${ }^{13}$ The primary evil they focus on is the sociopolitical and economic order, with witch discourses merely secondary symptoms of, and insightful social commentary on, that order. The mode of analysis of many anthropologists in this tradition is to ascribe meanings to the witch discourses other than the conscious meanings in the minds of those generating such discourses. ${ }^{14}$ In this anthropological tradition, beliefs are treated "as metaphors" (West 2007), not as truth claims. Stories of cannibalistic witches are really commentary about predatory capitalism-which is metaphorically cannibalistic. So when Harry West heard people in Mozambique report on witches that turn into lions and kill people, he summarized his analysis arguing that these stories of witch-lions involved metaphoric commentary on contemporary "predatory" unjust economic behaviors. But his Mozambican audience simply remained puzzled by the analysis, replying that he had misunderstood. Human witches, and the human witches who turn into lions, are not symbols. They are real. Lions are lions. People are sometimes witches. And the people who turn into lions and kill people are both witches and lions. West acknowledges that the anthropological mode of analysis he had learned failed altogether to engage belief straightforwardly on its own terms, with the result being an almost total inability to carry on a meaningful conversation across cultural divides about the meaning of witch discourses.

While Kenyan anthropologist Mwenda Ntarangwi quotes the Comaroffs, he clearly recognizes and indicates that our Kinshasa report differed in its approach from that of the Comarroffs (pp. 119-120). Specifically, he acknowledges the adverse outcomes of witch accusations on actual accused children and makes this recognition central to his own treatment. Furthermore, he provides a nuanced and compelling discussion of belief and worldview, and of how Christianity itself enables a possible engagement at the level of belief and of belief transformation.

\section{Theological and Philosophical Considerations}

This journal theme issue is intended not only to foster engagement with anthropological considerations but to move into a discussion of theological considerations also. And respondents clearly were concerned to address such matters also. Nigerian theologian Dr. Samuel Kunhiyop $(2002,133)$ identifies two sorts of philosophical/theological considerations that we should attend to when considering witchcraft: epistemology and metaphysics/ontology.

\section{Epistemology}

Epistemology poses the question of how one knows something to be true. Kunhiyop reminds us that simply because people believe something is true, does not mean that it is true (2002, 133-134). Dr. Andy Anguandia-Alo emphasizes a similar point in his response (pp. 55-56), as do others (Banda, CookeyEkpo, Gibbs, Gifford, Madueme, McKee, Ngolo, Ngong, Obot, Rasmussen). And if the truth claim is unusually consequential-such as the claim, "Nzuzi murdered his mother through witchcraft," then it becomes extremely important that such a claim about Nzuzi be subjected to careful scrutiny. How do we know Nzuzi actually caused his mother's death through witchcraft? Such a question requires attention to both epistemology and ontology. And indeed, each is dependent on the other.

\section{A. Diviners, Shamans, Witchdoctors, and Prophets}

In traditional societies with witchcraft ontologies, that is, in societies where it is believed that people's misfortunes are caused by other people with the ability to exercise invisible witch power to harm, such beliefs demand, and are normally accompanied by the presence of matching beliefs about an epistemology that permits such invisible agency to be reliably detected and perceived. And normally this involves the belief that a certain class or classes of persons have the preternatural ability reliably to discern who is exercising invisible witch power to harm. In the Amazon, this knowledge

\footnotetext{
${ }^{13}$ Peter Geschiere's recent book (2013) represents a partial break with this tendency, as Geschiere now recognizes that witch discourses do contribute to pervasive patterns of interpersonal distrust.

"There is indeed a long history in anthropology of treating verbal assertions about beliefs involving supernatural realities not as actual
claims about ultimate reality (which an "intellectualist tradition" within anthropology affirmed), but by reinterpreting such verbal
assertions about belief as actually symbolic or metaphoric of the social order (what Skorupski calls a "symbolist approach"). Claims
about supernatural realities were symbolic ways of talking about actual empirically observable social realities among people. For a
review and critique of this old tendency (present within functionalism, and later in Marxist inspired approaches), see Skorupski (1976).
} 
specialist is typically referred to as a shaman. ${ }^{1.5}$ In Africa, such traditional categories of persons with assumed expertise are most frequently referred to (in English) as “diviners" or "witchdoctors." Such magico-religious professionals appeal to their mastery of divinatory rituals and techniques and knowledge of relevant signs, and to their own preternatural capacity to know, to see, or even to "smell" the witch (Sanou, p. 146).

Nyasulu and Mlenga provide a rich description of tensions felt by many fellow Malawian Christians today. In a country that is majority Christian, Christians often retain a witchcraft ontology, with "nearly every sickness, death or misfortune interpreted as caused by witches" (Mlenga, p. 99). And yet mainline churches forbid them to seek help from diviners, and punish them when they do (Nyasulu, p. 124). Their witch ontology, which their churches failed to persuasively discredit, requires an accompanying epistemology that the mainline churches simply do not offer. Thus, many surreptitiously seek help from non-Christian diviners (ibid). There is necessarily an inherent tension in having a witchcraft ontology without an accompanying epistemology for tracking and counteracting the exercise of such invisible evil power. But more recently, as both Mlenga and Nyasulu point out, other churches increasingly offer the divination route to knowledge traditionally offered only by diviners. Under the rubric of a Christian vocabulary of prophecy, some churches host prophets said to be "endowed with the gift of uncovering hidden things," prophets who are able to "smell out who is a witch or not” (Mlenga, p. 100). In a competitive religious market place, as people leave older churches for newer churches that can help them address witchcraft, older churches rethink their ministries, with even some Malawian CCAP pastors conducting "deliverance sessions for children accused of witchcraft” (Nyasulu, p. 124). In our survey of Kinshasa pastors, $77 \%$ of respondents report that in their own church certain church leaders are believed to have the ability to identify who is or is not a witch (Priest et al., p. 26), with a high percentage of respondents (69\%) indicating that in child accusation cases they were familiar with, people concluded the child was a witch, at least in part, because a pastor, prophet, or intercessor identified them as such (Priest et al., p 24). A puzzle in all this, as Dr. Nyasulu points out, is that "African pastors, bishops, prophets or apostles" are doing "exactly what the diviners did before Christianity came” (Nyasulu p. 125).

\section{B. Supposed Evidences of Witchcraft}

And yet, usually, diviners and prophets alike do not merely appeal to their own raw authority, but also make an appeal to a larger epistemology of supposed evidences to back up their assertions with ostensibly independent evidence that they can appeal to. This evidence related to such things as dream content, confessions, or even visible signs that one is a witch.

Indeed, some respondents (Zehner, pp. 149-152; Ntarangwi, pp. 118-121) expressed appreciation that the EPED pastoral team did not attempt to critique the entire metaphysic of witchcraft causality but rather focused on the more modest epistemological concern with how specific people arrive at the conclusion that a specific child was the cause, through witchcraft, of misfortune in the life of another. By focusing the concern at this level, it remains clear what is at stake. To accuse someone of murder and have others accept the accusation as true is enormously consequential, with the Bible itself repeatedly cautioning against the possibility of people testifying against others to consequential falsehoods. Thus, the issue framed by EPED pastors in the context of real-life accusations of children cannot be understood as purely "theoretical" or "hypothetical." Justice itself, for actual real children, is at stake. Furthermore, in concrete settings where someone is accused of harming another through witchcraft, it is possible through careful inquiry to actually elucidate the proposed evidence and logic upon which the accusation is based-and to subject such purported evidence and logic to careful scrutiny. Thus, following Kunhiyop's recognition that the logic of evidences and proofs has direct consequences for the accused, our research explored inductively the claimed evidences of witchcraft that pastors appealed to-ranging from dream content to sleep disturbances. The intent of our research focus on epistemology, and of EPED pastoral focus on epistemology when defending children, was not to mock or laugh at the supposed "absurdity" of cultural ideas, ${ }^{16}$ but to help people understand the relevant phenomena being appealed to in straightforward ways that do not imply or require a witch interpretation. In the earlier history of European witchcraft, witch accusers similarly appealed epistemologically to "spectral evidence," to the presence of moles ("witches teats") on someone's body, or to the presence of a spot on the body impervious to pain (tested through "pricking” by specialist prickers) as evidence that someone was a witch. Pivotal to the

\footnotetext{
${ }^{15}$ Mike Mtika argues in his response to our paper that witchdoctors can "tell who is a witch or not while the shaman can only talk of evil things that a person is experiencing" (p. 109). While it is true that shamans in some cultures that do not stress witch ontologies (such as in Korea) do not use their claimed power to name witches, in cultures that do have witch ontologies, the shaman does claim the power to name witches and to counteract their evil (see R. Priest 2015b; Brown 1989)-and for purposes of this analysis such shamans are not meaningfully different from what Mtika calls "witchdoctors."

${ }^{16}$ As Dr. Mike Mtika seems to have inferred, p. 108.
} 
European eventual repudiation of witch trials and executions was the growing recognition that these supposed proofs provided epistemologically flawed grounds for convicting anyone of being a witch. The eventual decisive repudiation by Boston ministers of the validity of spectral evidence, for example, played a key role historically in the cessation of witch hunts and executions in New England.

There are children on the streets of Kinshasa today because pastors affirm that their bedwetting, their dreams of flying, their nightmares provide proof that they are witches. This is why EPED pastors subject such supposed proofs to critique. Both EPED pastors and other similar pastoral groups reported on by Howe and Stockley (pp. 74-79) achieve much of their success by their effectiveness in critically engaging the folk epistemology of supposed witch-guilt. Likewise, respondent Maïmouna Jessica Obot (p. 129-131), as a lawyer herself, has a special concern for flawed evidences being appealed to. In her own work training pastors in Nigeria, she explicitly critiques such supposed evidences of child-witchcraft. She indicates that in the earlier history of the region of Germany where she now lives many children were accused and sometimes burned at the stake for witchcraft. And it was a Christian lawyer, like herself, the professor of law Friedrich von Spee, whose writings critiquing the use of flawed evidences in witch trials proved influential in the eventual demise of witch hunts in his region of Europe (Obot, p. 130). Epistemology matters.

\section{Confession: The Ultimate Proof}

As our Kinshasa research showed, the confession of the alleged witch him or herself is often the most important culminating evidence appealed to (Priest et al., pp. 23-27, 33, 37). Indeed, the sole respondent in this theme issue to explicitly defend the idea that children can indeed harm others through witchcraft was the Congolese theologian Dr. Paul Mpindi. While his own graduate training was in biblical and theological studies, his actual defense of the idea that child witches cause harm through supernatural powers is not based on any exposition of biblical teaching, but on an exposition of witch confessions. Specifically, he appeals to an experience he had (pp. 105-106) where two young children in Kinshasa, a 14-year-old girl and her 10-year-old brother, confessed that they caused their father's blindness through witchcraft. He reports that he "led them to Christ," and had them "renounce the devil and sorcery as well."
Because of the centrality epistemologically of witch confessions to witch ontologies, before reflecting further on the possible implications of witch confessions, consider three additional contrastive confessions, one from Nigeria, one from Kinshasa, and another from New Guinea.

Case \#1: Rev. Haruna Tukurah was called to the home of a dying woman in Nigeria, where the woman's six-year-old daughter was said to have bewitched her mother. Rev. Tukurah recounts ${ }^{17}$ asking the little girl if it was true that she was a witch and had caused her mother's sickness. "Yes," the little girl replied. "How did you do it?" Tukurah asked? "Like this," she answered, as she revolved her hands in a circular motion. Tukurah told her, "Your mother loves you and takes care of you. She is about to die. Do you want her to die?" Shaking her head violently back and forth, the little girl sobbed, "No! No!" "Do you think you could undo your witchcraft?" Rev. Tukurah asked. "I'll try!" she replied, and reversed the order of her circular motions. Rev. Tukurah recalled the little girl sobbing and convulsively rotating her hands ... as her mother, a short while later, breathed out her last.

Case \#2: While in Kinshasa in May of 2017, I met the French photojournalist Gwen Dubourthoumieu ${ }^{18}$ who described photographing and hearing the following public confession of a thirteen-year-old girl in a Kinshasa church that emphasized deliverance of child witches.

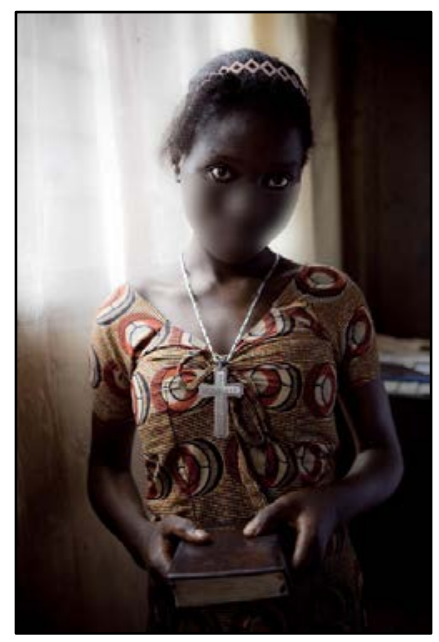

'I was inducted into witchcraft by my father's older brother when I was six years old. I became the wife of Lucifer and we had two children. I bewitched people using my eyes. When I looked at someone I

\footnotetext{
${ }^{17}$ Rev. Haruna Tukurah shared this account at a chapel I attended (January 18, 2012) at Nairobi Evangelical Graduate School of Theology in Kenya.
}

${ }^{18}$ Gwen Dubourthoumieu granted permission (May 15, 2017) to include this account and use this picture. 
neutralized his thoughts so that I had the opportunity to kill him easily.'Bénie, 13 years old.

Case \#3: In a New Guinea village, split evenly between Anglicans and Nazarenes, a dispute left an old widow feeling wronged, but without social recourse. Weeks later the wife of the village headman died, and the old woman was blamed for the death, accused of being a witch. She denied the charge but was beaten until her ribs were cracked and her arm and hand bones crushed. She eventually confessed that she was a witch, that she had caused the death, and that she had two accomplices. The two women that she named confessed more quickly than she had, and thus were not beaten as severely. Neville Bartle (2001, 320-325; 2005, 314-321), who recounts the incident, arrived a few days after these events, and describes the old woman as "the most pathetic, shriveled up woman I have ever seen." Locked up, she had not been given food or drink for five days. She had a high fever, and pus drained from her hand into a puddle in the ashes. A missionary gave her water and the Nazarene village pastor questioned the three women before the missionaries. Each woman reaffirmed their witch confessions. The old woman was then told that "although she had committed many evil deeds, there was forgiveness and salvation through faith in Christ." The pastor "led the women in a sentence-bysentence prayer of confession and repentance." The old woman died the next day.

It is worth keeping in mind that witch confessions are rather different from the relatively straightforward confession that one has stolen food from the kitchen, or even that one has participated in a forbidden ritual practice. In witch confessions, one is confessing to having harmed another through witchcraft. In Dr. Mpindi's case, the children confess that they caused their father's blindness. In Rev. Tukura's account, a sixyear-old girl confesses to causing her mother's illness (and death). In Bénie's account, she confesses to using her eyes to kill people. And in the New Guinea women's case, they confess to murder. In short witch confessions are simultaneously assertions of a witch ontology. They constitute, in other words, an assertion of a theodicy-an explanation of misfortune, suffering, and death.

And witch confessions are frequently simultaneously also witch accusations against others. Dr. Mpindi's two children named an aunt as a witch also; Bénie identified her father's older brother as also a witch, and; the elderly New Guinea woman named two other women as also being witches. To accept the confession as true requires accepting the metaphysical view that afflictions are supernaturally caused by witches, and it requires accepting the consequential truth that secondary persons named in these accounts are also guilty of being witches who harm and kill others. And in the case of Bénie, it involves the additional idea that humans can marry and have offspring with demons. If one collected such confessions across the history of witch confessions worldwide, one would find an astonishing range of beliefs about the powers and activities of witches-many of which, by criteria of historic Christian orthodoxy, would seem to be less than fully orthodox.

Dr. Mpindi reports (p. 105) that "these two kids told me so much about the inner workings of the dark world" that they could not possibly "know so much about sorcery without themselves being sorcerers." But in the social world of Kinshasa where witchcraft stories are ever present, in homes, churches, and on TV (Pype 2012), it should not surprise that many children know a great deal about shared cultural ideas of how witchcraft works. Furthermore, those who've studied such confessions report that a high proportion of witch confessions emerge after an earlier history of witch suspicions-with significant social efforts to pressure suspects into confessing and then naming other witches. One goal of witch hunts the world over is to elicit persuasive confirmatory confessions. Such confessions can then be repeated to new audiences. From the famous witch hunt of Salem, Massachussetts to Navaho witch inquiries, to the just mentioned New Guinea witch confessions, those who refused to confess faced torture and even death. Those who confessed, and then named some other person as also a witch, fared far better.

In Kinshasa, as we've seen, it is also believed that a child might not even know they are a witch, and only by examining such things as dream content is one able to know this. Children are coached to understand their dreams as actual memories of what they have actually done. In Kinshasa, children grow up hearing lurid stories of witchcraft. They are warned frequently never to accept food from strangers lest the food be a means to turn them into witches. So when they go to sleep hungry, as many orphans or step-children do, it is hardly surprising that they dream of food, of a stranger offering them tempting food, food which they accept, but where their dream immediately transitions to some of the very witch outcomes their culture has taught them will naturally result. On one model, cultural cuing produces the very dream content that can then be pointed to as evidence of witchcraft. Many confessions, as Onyinah (2012, p. 53) documented, are based purely on dream content-although usually public confessions do not disclose this fact.

And even if confessors truly have encountered a world of Satanic darkness, given that Satan is presented in Scripture as the great deceiver and accuser, why would one trust them to grasp and convey clear and accurate understandings of that dark supernatural 
world, of how it is that the evil of affliction occurs, and of which humans truly caused such afflictions?

\section{The Test of Scripture}

Christians have historically believed that our knowledge of God and of supernatural realities is possible only because God desires to disclose such knowledge to us-with Scripture understood as revelation from God that should be trusted as reliable. Thus our initial report (Priest et al., 2020) suggested that the Bible historically has often been mistranslated and misinterpreted in supporting witch ontologies, and we invited a conversation about what Scripture does or does not affirm about the idea that some people cause misfortunes to other people by means of witchcraft. Dr. Paul Gifford (pp. 70-71) contends in his response that witch ontologies reflect the influence of a Pentecostal "enchanted imaginaire" in which pastors (such as Nigerian Daniel Olukoya) explicitly appeal to Scripture, but clearly read their convictions into the Bible, rather then deriving them from what the Bible actually affirms. "If, like Olukoya, one is determined to find this worldview in the Bible, one obviously can” (p. 71). While Gifford (p. 70) acknowledges that our article (Priest et al., 2020) raises translational and interpretive issues of "immense sophistication" in how Scripture has been translated and interpreted, and while he seems to agree with our suggestion that people have been wrong to understand Scripture as affirming witch ontologies, he nonetheless contends that engaging such a biblical discussion is destined to fail in a context where the enchanted witchcraft imaginaire is so tenaciously affirmed and taken for granted. People will interpret Scripture to say what they wish it will.

It is interesting to consider the many responses to our article in the light of Gifford's claim. Admittedly, our article focused most attention on the ministry of EPED, a ministry that does not directly challenge the witchcraft ontology-but nonetheless achieved success by challenging particular accusations of particular children based on particular sorts of flawed evidence. And, of course, our article touched on a wide variety of issues and invited responses from people with quite different sorts of disciplinary strengths. The result is that many respondents simply did not directly address one way or other the section of our article related to biblical interpretation. However many did recognize that there is an open issue to be discussed, and a number addressed this directly. Only Dr. Mpindi (p. 105) directly and unambiguously defended a witch ontology, contending that "witchcraft is real," that witches cause harm, and that "no true African will ever doubt that." But while he claims to have acquired his understandings through "biblical teaching and practices regarding spiritual warfare” (p. 105), he does not engage any specific text or any of our own article's discussions related to biblical interpretation-instead focusing on a witchcraft confession as core to his argument. Naturally, we would like to see him engage relevant biblical texts in light of our article, as well as the writings of others such as Adu-Gyamfi (2016), Kunhiyop (2002), or Onyinah (2001; 2012)-and not least in light of a number of the responses in this very theme issue (Banda, Cookey-Ekpo, Madueme, McKee, Ngong, and Rasmussen). Of course, the fact that he did not engage this discussion here, does not mean he might not do so at a future time.

By contrast, consider the response of Nigerian Old Testament scholar, Dr. Paul Cookey Ekpo, who comes from a region of Nigeria where children are routinely accused of being witches. He has done research on child-witch accusations in his home area and has also focused his Old Testament research on biblical passages historically understood as related to witchcraft. He engages exegetically a number of biblical passages and themes (e.g. "mystical witchcraft seed") touched on in our data. He writes,

As a biblical theologian, I have not come across any biblical text that teaches the 'witch' or 'witchcraft' idea where some people, through evil occult power, are secretly the cause of other people's misfortunes. I agree with Priest, Ngolo and Stabell when they say, "But we wish to illustrate the possibility that Christians have fundamentally misread their Bibles, and thus that a larger conversation is needed that involves the biblical text, later translations, anthropological categories, and theological reflections" (43). This is never more true than now and there is a great need to help most Christians in this direction. (p. 63)

Cookey Ekpo's article interacts in affirming ways with a variety of core claims made in our article about what Scripture does, or does not, affirm. The article by Dr. Steve Rasmussen is particularly interesting in this respect, as it documents a process whereby a whole group of Tanzanian pastors went through a transformative conversation about what Scripture did or did not teach about the causes of affliction, and in which they embraced a transformed metaphysic and model of spiritual warfare. They retained robust ideas and practices related to the demonic but came to reject the witch ontology.

In short, while Gifford is not wrong to think that some people are likely to be impervious to careful reconsiderations of epistemology (and of Scripture)-an attribute not uncommon around the world-he is wrong if he was intending to make this a blanket generalization about African theologians and pastors. The very nature of this theme issue, and of the range of responses presented, demonstrates the possibilities of new 
conversations and emerging understandings of these difficult matters. Scripture, of course, is only one part of various sorts of considerations that must be engaged on behalf of moving us forward into better understandings and ministry practices. The next section will briefly review responses that relate to Kunyihop's concern with metaphysics and ontology-while also continuing the discussion of Scripture.

\section{Metaphysics/Ontology}

While Cookey Ekpo engaged metaphysical issues exegetically, the Cameroonian theologian Dr. David Tonghou Ngong, explores witchcraft ontologies in worldview terms. He reports that many foundational issues are "located in the social and cultural imaginaire into which people are socialized and from which they draw their interpretations of the world" (p. 115). Furthermore, this imaginaire is often "seen as central to the growth of Christianity in Africa, as the Ghanaian theologian Kwame Bediako claimed” (p. 115). The problem, Ngong contends, is that "the notion of witchcraft" is a core part of this "spiritualized imagination." He writes,

This imagination has been hailed in the study of African Christianity as the fertile soil that has led to the growth of the Christian faith in Africa. Thus, rather than challenging this imagination, it is sometimes presented as an imagination that needs to be nurtured in order to fend off atheism or the westernization of African Christianity. (p. 116)

This poses, in his view, difficult questions (p. 115, 116), including the following. "Does Christianity enjoy the possibility for growth only where the witchcraft imagination is preserved?" "How can one save the church from an unholy alliance with the accusation of children as witches while at the same time ensuring that Christian belief is not adversely affected?" And again, "Is the Christian faith or Christian theology capable of arresting an imaginaire that seems to give it life?"

Ngong reminds readers that EPED pastors worked to combat specific accusations of child witchcraft, but were unwilling to consider a critique of the entire witchcraft worldview, instead signaling that any theologian or pastor who advocated this was not to be trusted. By contrast, Ngong calls for a "frontal challenge to the worldview" that gives witchcraft life (p. 116). He writes,

While the individualized pastoral response this project encourages may begin to challenge this worldview, the fact that the pastors who administer the process themselves do not seem to be critical of the belief in witchcraft seems to skirt the foundational problem for the symptom. It may well be that challenging the symptom may eventually lead to addressing the foundational imaginaire that breeds it. However, a direct challenge of this imaginaire is still needed. (p. 116)

Again, the report by Rasmussen (2020, pp. 137-141) on Pentecostal pastors would seem to provide one example of a group of pastors at a grass-roots level, where some pastors are actually going through a paradigm shift of a sort envisioned by Ngong, one that calls into question the underlying witchcraft ontology.

As a theologian, Dr. Collium Banda (2020, pp. 5760) likewise invites us to consider the issues in theological terms. He draws from his expertise on African Traditional Religion (ATR) and develops the argument that churches practicing child-witch deliverance are promoting a flawed soteriology, one which owes its logic (an "impersonalization of God" leading to "superstitious solutions") to African Traditional Religion rather than to a biblical soteriology. His insightful analysis and biblical exposition merits careful attention.

As an anthropologist and former missionary linguist, Dr. Rob McKee, likewise frames his response in theological and biblical terms, appealing specifically to the doctrine of creation. He argues that Scripture teaches that people and the rest of creation are created entities that exhibit only those powers with which they are endowed by their creator, but that people continually and imaginatively wish to ascribe attributes and powers to created entities or persons that they were never endowed with. We should neither imagine, nor fear, nor ascribe such supposed powers to persons or idols-as various biblical passages teach.

Finally, the systematic theologian (and former medical doctor) Dr. Hans Madueme (2020, pp. 83-86), suggests that against the backdrop of Western naturalism, it is easy to imagine supernaturalism as a single unitary contrasting system. But he invites us to recognize that worldwide there are diverse forms of supernaturalism-none of which should be assumed uncritically to be precisely the same as the supernaturalism found in Scripture. He calls for us to subject our notions of supernaturalism, including those tied to beliefs about witch powers, to Scriptural scrutiny. Indeed, he argues that "adopting the Protestant Scripture principle (sola scriptura) rules out indigenous notions of witchcraft” (p. 84). He writes,

In the first place, I do not apologize for privileging sola scriptura. Any theological tradition that does not habitually align itself with the teaching of Scripture deserves to die. "The grass withers and the flowers fall, but the word of our God stands forever" (Isa 40:8). In the second place, taking the Bible 
seriously is not a Trojan horse for the compromises of Western Christianity. True allegiance to Scripture is a long way from the "excluded middle" Paul Hiebert warned against in his classic essay (1982). As believers who are united with Christ and empowered by the Holy Spirit, we are de facto protagonists in a life-and-death spiritual warfare. African Christians can help the global church retrieve an unflinchingly biblical supernaturalism. However, African Christianity will only lead the way if it jealously guards the canonical witness and its rule over the life of the church. (p. 84)

Madueme concludes with a number of suggestions for how to foster "a richer, supernatural, and truly African theology, magnificent in all its glory, yet always in continuity with the catholic tradition and rooted in the whole counsel of God” (pp. 85-86).

\section{Conclusion}

I am deeply grateful to the 31 scholars who took the time to read our research report on "Christian Pastors and Alleged Child Witches in Kinshasa, DRC," and who also took time to engage the issues from their own experience and expertise, sharing their insights and reflections with us in 29 articles. I am deeply aware that this final summary of, and response to, critiques and commentaries of these other scholars on this subject fails to do full justice to them. But I hope it gives a sense of the range of insightful treatments which they represent, and that it points readers back into the reading and rereading of each of the preceding contributions, and perhaps even to the assignment of selected of these readings, as well as others, ${ }^{19}$ in pastoral and theological training settings.

Many of the authors expressed deep appreciation for the opportunity to engage in this sort of interdisciplinary and global conversation about these important matters and expressed hope that the conversation in this journal theme issue would work its way into African theological educational institutions. One finds here pastoral concern, awareness of anthropological dynamics, theological reflection, and field-based research that should inspire others to ask new questions, to engage in more cross-disciplinary reading on the topic, to carry out additional strategic research, to publish research results, to tell the stories of how Christians are engaging these matters-and with what outcomes. May God grant us wisdom, vision, and motivation to move us forward, as Christian scholars, in attempting through our scholarship to help the wider body of Christ fulfill its calling in biblical, contextually healthy, and God-blessed ways.

\section{References}

Adeney, Miriam. 2020. What is natural about witchcraft? $O n$ Knowing Humanity Journal 4(1): 52-54.

Adu-Gyamfi, Yaw. 2016. "Thou shalt not suffer a witch to live" (Exod 22:18) and contemporary Akan Christian belief and practice: A translational and Hermeneutical Problem. Old Testament Essays 29 (1): 11-32.

Anguandia-Alo, Andy. 2020. Conversation time has come. On Knowing Humanity Journal 4(1): 55-56.

Banda, Collium. 2020. A soteriological response to the Congolese pastor's engagement with children accused of being witches. On Knowing Humanity Journal 4(1): 5760 .

Bartle, Neville. 2001. Developing a contextual theology in Melanesia with reference to death, witchcraft, and the spirit world. DMiss Dissertation, E. Stanley Jones School of World Mission and Evangelism, Asbury Theological Seminary.

- 2005. Death, witchcraft and the spirit world in the highlands of Papua New Guinea: Developing a Contextual Theology in Melanesia. Melanesia Institute.

Brown, Michael. 1989. Dark side of the shaman. Natural History (November): 8-11.

Cookey Ekpo, Paul. 2020. A biblical scholar's response to issues in "Christian pastors and alleged child witches in Kinshasa, DRC.” On Knowing Humanity Journal 4(1): 61-64.

Douglas, Mary. 1970. Introduction: Thirty years after Witchcraft, Oracles, and Magic. In Witchcraft confessions and accusations. Mary Douglas, ed. Pp. xiiixxxviii. London: Tavistock Publications.

Foster, George. 1972. The anatomy of envy: A study in symbolic behavior. Current Anthropology 13 (2): 165202.

Geschiere, Peter. 2013. Witchcraft, intimacy, and trust: Africa in Comparison. Chicago: University of Chicago.

Gibbs, Philip. 2020. Witchcraft accusations and hybrid formulations in Papua New Guinea. On Knowing Humanity Journal 4(1): 65-68.

\footnotetext{
${ }^{19}$ There are, of course, other excellent treatments by African theologians of this topic, not least the collection of blog postings on the topic written for the Carl F. H. Henry Center for Theological Understanding [henrycenter.tiu.edu/witchcraft-accusations/] by Anguandia-Alo, Asamoah-Gyadu, Gitau, Kunyihop, Mavinga, Mombo, Mugambi, and Onyinah, as well as by Priest, Rasmussen, and Stabell (see Priest 2015a).
} 
Gifford, Paul. 2020. A dysfunctional worldview. On Knowing Humanity Journal 4(1): 69-71.

Girard, René. 2001. I see Satan fall like lightning. Maryknoll, NY: Orbis Books.

Gitau, Wanjiru. 2020. Christian pastors and alleged witches in Kinshasa, DRC: A response. On Knowing Humanity Journal 4(1): 72-73.

Howe, Susie and Paul Stockley. 2020. Reframing thinking and action: A way forward in responding to child witch accusations through contextualized participatory engagement. On Knowing Humanity Journal 4(1): 74-78.

Jindra, Michael. 2020. Social instability, churches, and child witchcraft. On Knowing Humanity Journal 4(1): 79-80.

Kluckhohn, Clyde. 1967. Navaho witchcraft. Beacon Press.

Kunhiyop, Samuel W. 2002. Witchcraft: A philosophical and theological analysis. Africa Journal of Evangelical Theology 21(2): 127-145.

Lumeya, Nzash U. 2020. Christian pastors and child witches in Kinshasa, DRC. On Knowing Humanity Journal 4(1): 81-82.

Madueme, Hans. 2020. A theological critique of witchcraft: Ruminations from a fellow African. On Knowing Humanity Journal 4(1): 83-86.

McKee, Robert Guy. 2020. The Bible's cultural mandate, child witches, cognitive authority, and Christian pastors. On Knowing Humanity Journal 4(1): 87-91.

McKinney, Carol V. 2020. Comments on Christian pastors and child witches in Kinshasa, DRC. On Knowing Humanity Journal 4(1): 92-94.

Minkema, Kenneth P. and Phillip D. Davis. 2020. Witchcraft accusations in comparative contexts: The early modern European witch-hunts and alleged child witches in the Democratic Republic of the Congo. On Knowing Humanity Journal 4(1): 95-98.

Mlenga, Joyce Dainess. 2020. Witchcraft accusations and the Christian church's response. On Knowing Humanity Journal 4(1): 99-102.

Mombo, Esther. 2020. Do witches exhume dead bodies? On Knowing Humanity Journal 4(1): 103-104.

Mpindi, Paul M. 2020. Child witches in Kinshasa, DRC: A response. On Knowing Humanity Journal 4(1): 103-107.

Mtika, Mike. 2020. A contribution to the conversation. On Knowing Humanity Journal 4(1): 108-110.

Ngolo, Abel. 2020. Overview of the work of the Pastoral Team for Children in Need (EPED) in its struggle against the problem of so-called child-witches in the DR Congo. On Knowing Humanity Journal 4(1): 111-114.
Ngong, David Tonghou. 2020. What is the disease? Engaging the problem of witchcraft in Africa. On Knowing Humanity Journal 4(1): 115-117.

Ntarangwi, Mwenda. 2020. Straddling two worlds: Christian leader's responses to witchcraft accusations in the DRC. On Knowing Humanity Journal 4(1): 118-121.

Nyasulu, Timothy Kabulunga. 2020. Witchcraft accusation and church discipline in Malawi. On Knowing Humanity Journal 4(1): 122-128.

Obot, Maïmouna Jessica. 2020. To end child witch accusations: A task for the whole church. On Knowing Humanity Journal 4(1): 129-131.

Onyinah, Opoku. 2004. Contemporary 'witch-demonology' in Africa. International Review of Mission 93 (3): 330-345.

- 2012. Pentecostal exorcism: Witchcraft and demonology in Ghana. Dorset, UK: Deo Publishing.

- 2020. "The person I hate most in my life is my mother." On Knowing Humanity Journal 4(1): 132-134.

Priest, Chinyere Felicia. Witchcraft labeling: Effects on child behavior and self-concept. On Knowing Humanity Journal 4(1): 135-136.

Priest, Robert J., ed. 2015a. An International Blog Conversation about Witchcraft Accusations and the Church, based on blogs at the: henrycenter.tiu.edu/witchcraft-accusations/, available at: www.academia.edu/40619650/Blog_Conversation_Abou t_Witchcraft_Accusations_and_the_Church

Priest, Robert J. 2015b. Putting witch accusations on the missiological agenda: A case from Northern Peru. International Bulletin of Missionary Research 39: 3-6.

Priest, Robert J., Abel Ngolo and Timothy Stabell. 2020. Christian Pastors and Alleged Child Witches in Kinshasa, DRC. On Knowing Humanity Journal 4(1): 1-51.

Pype, Katrien. 2012. The making of the Pentecostal melodrama: Religion, media, and gender in Kinshasa. New York: Berghahn.

Rasmussen, Steven D. H. 2020. Significance of this research and a Tanzanian case study. On Knowing Humanity Journal 4(1): 137-141.

Rynkiewich, Michael Allen. 2020. Response to Priest, Ngolo and Stabell. On Knowing Humanity Journal 4(1): 142144 .

Shweder, Richard. 2003. Why do men barbecue? Recipes for cultural psychology. Harvard University Press.

Skorupski, John. 1976. Symbol and theory: A philosophical study of theories of religion in social anthropology. Cambridge: Cambridge University Press.

West, Harry G. 2007. Ethnographic sorcery. Chicago: University of Chicago Press. 
Zehner, Edwin. 2020. Comment on the article, "Christian pastors and child witches in Kinshasa, DRC," by Robert J. Priest, Abel Ngolo and Timothy Stabell. On Knowing Humanity Journal 4(1): 149-152.

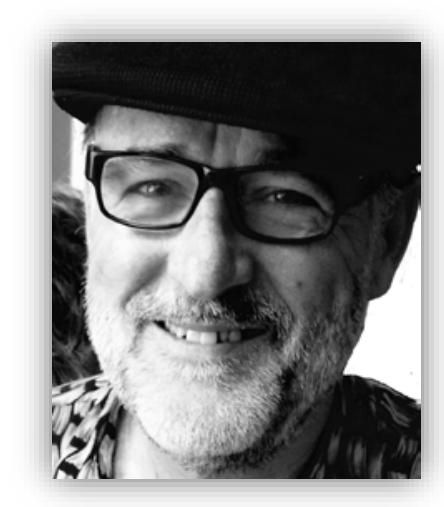

Robert J. Priest is Professor of Anthropology at Taylor University. He has served as president of both the American Society of Missiology (2013-14) and the Evangelical Missiological Society (2015-17). For a decade he directed the Ph.D. Program in Intercultural Studies at Trinity Evangelical Divinity School. While at Trinity, he served as the primary dissertation supervisor for 36 Ph.D. students. His research and writing have included a focus on the anthropology of religion, race and ethnicity, sexuality and marriage, short-term missions, religious conversion, contextualization, missiology as a field, and witchcraft accusations. On occasion, he has coordinated teams of senior scholars working together on specific research and writing projects, such as in the Africa Leadership Study (2008-2018), where results were published in a 2019 book co-edited by Robert Priest and Kirimi Barine: African Christian Leadership: Realities, Opportunities, and Impact (Orbis/Langham).

Author email: robert_priest@taylor.edu 